\title{
Complexity Theory for a New Managerial Paradigm: A Research Framework
}

\author{
Gandolfo Dominici and Vasja Roblek
}

\begin{abstract}
In this work, we supply a theoretical framework of how organizations can embed complexity management and sustainable development into their policies and actions. The proposed framework may lead to a new management paradigm, attempting to link the main concepts of complexity theory, change management, knowledge management, sustainable development, and cybernetics. We highlight how the processes of organizational change have occurred as a result of the move to adapt to the changes in the various global and international business environments and how this transformation has led to the shift toward the present innovation economy. We also point how organizational change needs to deal with sustainability, so that the change may be consistent with present needs, without compromising the future.
\end{abstract}

\section{Introduction}

The world today face numerous long-term challenges, including climate change, population aging, desertification, water scarcity, pollution, outbreaks of incurable viruses, and critical scarcities of raw material (Montalto et al., 2012; Winn, Kirchgeorg, Griffiths, Linnenluecke, \& Günther, 2010). The solutions to these problems constitute the main challenge of our times. It is necessary to find new ways to develop the economy and society, salvaging the consequences of the changes of the twentieth century (Luhmann, 1989), which are still ongoing in the present century. To this end, it is necessary to be aware of and observe moral and ethical principles.

\author{
G. Dominici $(\bowtie)$ \\ Department SEAS, Polytechnic School, University of Palermo, Palermo, Italy \\ Business Systems Laboratory, Avellino, Italy \\ e-mail: gandolfo.dominici@libero.it \\ V. Roblek \\ Faculty of Management, University of Primorska, Koper, Slovenia \\ e-mail: vasja.roblek@gmail.com
}


In this work, we supply a theoretical framework of how organizations can embed complexity management and sustainable development into their policies and actions. We see organizations as open systems (Hatch, 2012; Luhmann, 1986; von Bertalanffy, 1973) whose behavior is influenced by various strategically relevant perturbations from the external environment, with an emphasis on the global nature of social, cultural, and religious specificities of individual countries and regions. Such organizations are also part of the context (Luhmann, 1995; Meyer \& Rowan, 1977; Rice, 2013), and so it is crucial for them to be able to recognize and evaluate how their contexts of action are influenced by environmental changes. If we consider organizations as viable systems aiming to survive in the context (Beer, 1972; Dominici \& Palumbo, 2013; Espejo \& Reyes, 2011; Golinelli, 2010), we can conclude that they need to maintain their integrity (autopoiesis) and see consonance (Golinelli, 2010) through partnerships with the relevant suprasystems (other organizations), in their context of existence and action. Smaller systems contribute to the development of the larger systems within which they compete for resources. If the system survives, it may be regarded as viable (Beer, 1972; Dominici \& Palumbo, 2013, Golinelli, 2010), and if it survives in the long term, it may be regarded as sustainable (Teisman, 2005).

The external environment (or context) can be theoretically explained by the complexity theoretical approach described by Luhmann's social system theory. According to the theories of composite systems, players in the market are subject to separate legislation and social rules; on the basis of which, they establish contractual relations and develop cooperation (Auyang, 2003) that is in consonance and resonance with the context (Dominici \& Palumbo, 2013; Golinelli, 2010). Market formation therefore derives from the abovementioned relations with ecological and social systems that have a significant impact on the organizations (Luhmann, 1995; Stacey, Griffin, \& Shaw, 2000). We can consider Luhmann's social system theory as being based on a complexity-sustainability trade-off (Valentinov, 2014). This trade-off implies that the sustainable development of organizations, and ultimately of the whole society, is associated with its increasing complexity (Csikszentmihalyi, 2004; Laszlo, 1972).

Though sustainability implies a long-term mode of thinking, it can be seen that short-term profitability mindsets are still prevailing (as shown by the financial crisis of 2007-2008) (Christopher Houghton, 2011; Jackson, 2010), resulting in business models that are not sustainable (Boons, Montalvo, Quist, \& Wagner, 2013).

In the years since the beginning of the crisis, increasing numbers of companies have begun to incorporate sustainability principles into their business operations, in order to achieve their business objectives (Carroll \& Buchholtz, 2014). Sustainability is now considered as a relevant part of reputation management, which includes energy saving, green product development, green certifications, and all other activities that can enable companies to achieve added value through growth and reputation capital (Panayotou, 2013). The best managers seek to ensure longterm corporate value by shifting their strategies and management to exploit the market potential for sustainable products and services, while at the same time successfully reducing and restricting the sustainable cost and risk (Bonini, 2012). 
Complexity theories help us to understand the organizational changes and strategies for providing sustainable business management. Significantly greater inclusion of the sustainability challenge by businesses would result from the holistic approach to connected knowledge activities (Mulej \& Potocan, 2007; Ny, Hallstedt, \& Ericson, 2013). Such holistic models include the promotion of sustainable development and applying the term sustainable beyond its environmental dimensions. The structural reforms include the promotion of long-term planning to ensure continuity in policy through social, political, and managerial changes.

\section{The Economic Paradigm Shift as a Premise for New Business Models}

In the first half of the 1980s, we saw a transition from "traditional heavy industry" to the technological development-oriented economy (Alexander, 1983). The world economy entered into a new "knowledge economy," which is an economy of organizations and networks. This implies a shift toward the actual liquid social and economic system (Bauman, 2000; Brinkley, 2006; Perry, Goodwin, Peck, \& Freeman, 2006). The new social and economic paradigm has brought organizational changes in strategies, structures, and management styles. Managers are expected to have control over the release, supervision, and use of resources, as opposed to the policies of the old economy, which emphasized the need for formal links and ownership of own resources (Bertoncelj, Kovac, \& Bertoncel, 2009).This shift is not, however, without risk. Pagano and Rossi (2009) argue that the specific cause of the last economic crisis was the knowledge economy. These authors claim that the cause of the crisis lays in the monopoly of developed countries over intellectual rights. International agreements regarding trade-related aspects of intellectual property have caused an increase in the cost of investment in countries that have neither abundant, inexpensive labor nor high amounts of intellectual property. In this framework, a relevant element in the solution to the actual crisis-besides changes in monetary policy, financial regulation, and standards of Keynesian economic policy — would require policies aimed at reducing the intellectual monopolization of the economic global system.

Changes in macro trends affect the uncertainty in the business environment. Organizations are being forced to adopt a comprehensive infrastructure based on a more flexible organizational structure, in order to implement on-demand marketing and technological innovation (Autry, Goldsby, \& Bell, 2013; Dominici, 2008). At the same time, it is necessary to realize that the ability to develop or obtain the basics of modern information and communication technology plays an important role in economic and social development (Bertot, Jaeger, \& Hansen, 2012).

Traditionally structured organizations are now facing compelling reasons to adopt policy change management and to reorganize their structures. At the same time, it is necessary to realize that the ability to develop knowledge and to deal with 
information and communication technologies plays an important role in economic and social development. Organizational changes, given their significant impact in terms of increasing productivity and efficiency, constitute added value and, consequently, promote the development of economy and society (Bisson, Stephenson, \& Vigurie, 2010; Kaplan \& Mikes, 2012).

The emergence of the Internet in the early 1990s has influenced the rise of the third wave of capitalism. The emergence of Internet technologies affects the speed and quality of changes in global markets; these are reflected in different ways in consumer behavior and, consequently, in the development of new business models (Roblek, Pejić Bach, Meško, \& Bertoncelj, 2013).

The great investment in information technology (IT) in the 1990s in the US did not lead to the expected effects, and the position of Alan Greenspan that the US would show high economic growth, low unemployment, and low inflation as a result of the development of IT has proven to be incorrect. Research carried out in 1998 in the US has shown that almost half of all projects initiated in the field of IT fail (Emerson, 2001).

The stock market crisis caused by the overvaluation of the shares of emerging technology organizations in the early twenty-first century brought new economy period to a close. Since then, we have witnessed the rise of a new kind of capitalism that combines some of the characteristics of the previous new economy paradigm with a stronger focus on innovation. We call this paradigm the "innovative economy;" it is a capitalist economic model in which innovation and intuition are the critical success factors (Kuula, Putkiranta, \& Toivanen, 2012; Walters, 2004).

This new business logic derives from the premise that economic growth in an innovative economy results from the final product or service, which is in turn created on the basis of knowledge (Antonelli, 2003). Thus, innovative entrepreneurship has emerged based on $R \& D$, the regulation of certain activities, venture capital, the enhancement of intellectual property (patents and licenses), and the encouragement of networking organizations that facilitate cooperation between businesses (e.g., clustering).

\section{Complexity Science in Management}

The concept of "system" is known from the period of ancient Greek civilization. However, the actual theoretical development of the systemic approaches occurred during and after the Second World War. Frank Fremont-Smith at the Josiah Macy, Jr. Foundation promoted the Macy Conferences for almost two decades from 1941 to 1960. These Conferences were a set of meetings of scholars from various disciplines held in New York, with the explicit aim of promoting meaningful communication across scientific disciplines and restoring unity to science. During these conferences, the foundations of system thinking and cybernetics were born.

In 1951, Ludwig von Bertalanffy conceived of and published the fundamentals of general system theory. This theory arose as a reaction to the dichotomy of science, whereby physics, chemistry, biology, economics, psychology, sociology, 
and other sciences individually explore and deepen their own scopes, creating theories, solutions, and models that are useful only in their narrow segment (von Bertalanffy, 1951). General system theory, in contrast, acts as an integrator of the various scientific fields.

Boulding (1956), in his highly publicized article "General Systems Theory: The Skeleton of Science," published a classification of the system in the form of nine hierarchical levels. Levels 1-3 include nonliving systems, such as closed physical systems. Levels 4-6 are the biological and open systems. At levels 7 and 8, the social and behavioral sciences are located. Here we find the human being with social systems to the forefront. These systems are open. The final, ninth, level contains religion, theology, and philosophy.

The entry of science into management theory came in the 1980s. Lynch and Kordis (1988) described complexity theory as a powerful new paradigm for business development, and Merry (1995) considered it an important organizational tool.

The development of information technologies in the 1970s led to the development of new channels of communication between the various systems attempting to steer each other. The second-order cybernetic approach bridged the micro-macro gap and has led to closer integration of the individual with society (Bailey, 2006). In the 1960s, Kieser and Kubicek (1992) developed a model for the contingency approach, where the analysis of events in the business environment requires an immediate response from managers and where business decisions must be prompt and timely. Structural contingency is a part of behavioral theory and of systems for settling a particular business information system. The theory proposes no single best solution. Effective and efficient management models cannot be easily adapted to unique environments. Each organization finds specific features and functions in its environment.

Second-order cybernetics focuses on research problems such as instability, flexibility, learning, change, evolution, and autonomy. In the 1980s, the question of whether the features of second-order cybernetics could be applied to social forms of organizations was raised (Staehle, 1991). Second-order cybernetics, together with system theory, forms the common systems-cybernetic approach to organizations and management (Elliott Dupuy, 1986; Staehle, 1991). The method is based on the fact that each organizational system is open. The organization as a closed system cannot exist, as it lacks viability (Beer, 1972; Golinelli, 2010). An organization is an open and connected system with the environment, and because of this, the organization needs to adapt to environmental changes (Beer, 1972; Golinelli, 2010; Stoner \& Freeman, 1992). The task of managers is to determine all the factors that affect the business within its particular environment and situation, to choose the right solution, and to monitor and provide expert guidance on the implementation of these solutions (Certo, 2000). A significant systemic property for the functioning of the organization as an open system is equifinality (Golinelli, 2010; Gresov \& Drazin, 1997). The organization can achieve the result and aim at different initial conditions in different ways. The organization is also in constant interaction with the environment. It adapts to the conditions imposed by the environment (both natural and social) in order to ensure its survival and progress. 
It is important to underline the key role of the concept of entropy in complex system theories. Entropy is a concept derived from thermodynamics, which expresses a measure of the number of specific states in which a thermodynamic system may be arranged - normally considered a measure of disorder. According to the second law of thermodynamics, the entropy of an isolated system never decreases. But an organizational system can reduce its entropy through selforganization and the ability to achieve negative entropy (Prigogine \& Stengers, 1984). Prigogine's "Dissipative Structure Theory" can be considered a bridge between the natural sciences and social sciences, as well as between general system theory and thermodynamics.

Stafford Beer in his book "Brain of the Firm" (1972), together with his earlier works on the application of cybernetics to management, paved the way for the use of cybernetics, variety, and complexity principles in the business management field and founded the research stream of management cybernetics. The Viable Systems Model (VSM) proposed by Beer is a set-theoretical model based on the system approach and on the cybernetic system's viability. The VSM integrates Ashby's law of requisite variety (LRV) and insights from neurophysiology (inspired by the work of McCulloch) for enterprises. The VSM conceives of the brain as an open system in constant interaction with the environment. When it receives an external stimulus, it can activate a decision-making process and convert perceptions into actions (Dominici \& Palumbo, 2013). Its mission is to control (Wiener, 1948, 1965) and synchronize all the organism's functions and to be adaptive and proactive in the contextual environment. This adaptation to the increasingly complex environment is today the main organizational challenge that management faces.

\section{The Characteristics of the New Complex Business Context}

The characteristics of the organization as an integrated open system, affected by complex system factors from the market and business environment, can be summarized as follows:

- Globalization: The organization is going for an enormously interactive social process. Information and communication technology enables constant interactivity, connectivity, and transparency, enabling leaps in productivity (Kaplan \& Haenlein, 2010). This is reflected in the various responses of consumer behavior and has a consequence in the development of new business models that include the sustainable development of the organization (Valacich \& Schneider, 2012). Many researchers agree that globalization has also led organizations and managers to behave more ethically and socially responsibly (Deresky, 2003).

- Impact of new technology on complexity in organizations: Technology and economic development have caused changes that have transformed the Taylor hierarchical organization into the knowledge organization (Burke, 2012). 
- Networking: Social networking allows not only access, transfer, and sharing of knowledge but also the creation of relationships between users, as new components communicate with each other. The potential added value of social communication channels anticipates the quality and safe access of knowledge for both individuals and the organization (O’Dell \& Hubert, 2011). The relationships that arise in social networks between individuals allow them to weave closer ties, while at the same time permitting individuals to discover each other's behavioral characteristics. This increases the importance of interactions on a personal and business level. Business networks are based on the development of trust between entrepreneurs and thus reduce business risk and various transaction costs (e.g., the legal costs of patent protection and the cost of finding and identifying appropriate techniques and technologies).

- Sustainable development and increased uncertainty in the business environment is forcing organizations to set the continually updating of comprehensive infrastructure as a strategic objective. As noted by Cohen (1999), the changes in structure and business operations, government, and nongovernmental organizations mean that managers are focused on the ideas of complexity theory. This calls for more flexible organizational structures (internal environment), the introduction of modern technologies for implementing relational marketing, and technological innovation (Sekerka \& Stimel, 2011). At the same time, it should be noted that the ability to develop and achieve at least basic environmental standards plays an important role in the success of both economic and social development. By achieving strategic goals, organizations will increase productivity, efficiency, and added value, consequently encouraging social and economic changes (Uhl-Bien, Marion, \& McKelvey, 2007).

On the outside, organizational market systems are ever changing, being continually redefined by the interaction of organizations; inside the organizations, then, the boundaries among subsystems become more permeable, allowing a bottom-up flow of ideas. This implies that, as in Prigogine's dissipative systems, organizations never stay in a status of equilibrium. In such a business environment, it is difficult to define and determine the appropriate business models, and no "one best way" is possible (Dominici, 2012); new means are emerging with different approaches, technologies, and considerations, undermining the traditional set rate of market shares.

In this view, the organization represents a system that is organized into two or more interdependent components named subsystems (Golinelli, 2010). Mikulecky (2010) highlights how the organizational subsystems have their peculiar characteristics which may differ from those of the whole system. Hence the organizational functions themselves are complex systems. In this framework, the impact of organizational changes on business processes may affect business policies toward the markets and toward the business' contexts. 


\section{The Challenge of Sustainable Management}

Sustainable management derives from the concepts of sustainability and installs them into those of management (Pearce, Barbier, \& Markandya, 2013).

The concept of sustainable leadership is defined in a systemic way, as a system of principles, processes, practices, and values that the company has accepted as an object for the exercise of their future. The word "sustainable" in this concept not only refers to a company that is "green" and socially responsible; research by Avery and Bergsteiner (2011a) on more than 50 companies around the world found that sustainable management requires making decisions that are long term, systemically promote innovation, and are aimed at increasing the added value for the customer; developing a skilled, loyal, and productive workforce; and offering quality products, services, and solutions. Sustainable management therefore requires management to take a macro view of the business, beginning with the fundamental question, "What is the purpose of the company?" (Avery \& Bergsteiner, 2011b).

van Kleef and Roome (2007) explain sustainable business management as the conduct of a business that has recognized the need for integration of the social, environmental, and economic systems and which focuses on the management and relationships needed to achieve the environmental, social, and economic requirements of the many different stakeholders in their network.

Sustainability encourages organizations to become aware of the importance of the effects of social, environmental, and economic systems in organizational culture, decision making, strategy formulation, and business operations.

The concept of sustainable management emerged in the 1970s (Barbier, 1987), but its ascent began after the publication of the Brundtland report in 1987 (World Commission on Environment and Development, 1987). The report defines sustainable development as development that meets the needs without compromising the ability of future generations to satisfy their own needs. van Tulder, Kolk, and Van Wijk (2009) consider that organizations need to take the economic experience into account, but should also adopt wider social and environmental perspectives (Yang $\&$ Sheu, 2007). Potocan and Mulej (2003) made clear that the understanding of the sustainable development requires holism, professional, and political aspects in synergy, with systems thinking as a background for the creative and innovative society.

The economic aspects of sustainability, along with the social and environmental aspects, provide organizations with competitive advantage that leads to viability and enables survival and further growth (Yang, Lin, Chan, \& Sheu, 2010). For the purpose of measuring organizational success and enhancing the need for focusing on the social, environmental, and economic impact on the corporate activities, the concept of corporate social responsibility (CSR) has been developed (van Tulder \& Van der Zwart, 2006):

- Environmental sustainability includes environmental reports, ecodesign and efficiency, environmental management systems, and executive management commitment to addressing environmental issues. 
- Economic sustainability includes codes of conduct and compliance, antipolitics, corporate governance, risk and crisis management, strategic planning, knowledge management, quality management, and supply chain management.

- Social sustainability includes corporate citizenship, philanthropy, labor practices, human capital development, social reporting, attracting and retaining talent, and engaging in dialogue with stakeholders.

The concept and practice of CSR go hand in hand with sustainability. The World Business Council for Sustainable Development (WBCSD) (1999) defines the CSR of organizations as their constant commitment to ethical behavior, economic development, and improving the quality of life of employees, their families, local communities, and society in general. They mention five priority areas of human rights, employee rights, environmental protection, integration into the community, and relationships with suppliers.

Corporate sustainability was defined by Elkington (1999), who developed the concept of a "triple bottom line." This derives from the point of view that long-term business goals are inseparable from the society and the environment in which they operate, while on the other hand, short-term economic gains can be achieved at the expenses of social and environmental suprasystems, this resulting in the wide diffusion of unsustainable business practices.

In 2011, the European Commission published a new policy on CSR. On the basis of the socioeconomic developments of the period following 2008, when the member states of the European Communities had been hit hard by the economic crisis, the revised document adopted a new definition of CSR as "the responsibility of enterprises for their impacts on society" (European Commission, 2011). The Commission believes that companies should consistently fulfill the aim of social responsibility by integrating social, environmental, and ethical issues, as well as issues regarding human rights and consumer concerns, into their business operations and core strategy, in collaboration with stakeholders. Companies should thus ensure that they act to optimize shared values for the owners or shareholders, stakeholders, and the community at large.

The Commission has urged large companies and companies in which the risk of harmful effects are especially pronounced to carry out due diligence procedures on the basis of risk in their supply chains; however, due to the complexity of the CSR process, in the case of SMEs and particularly of microenterprises, it is likely that the process will remain informal and intuitive.

\section{The Pillars of Sustainable Management}

Organizations operate in a social context in which they need to deal with governments and communities (Schwartz \& Carroll, 2003). The other actors in the context expect that organizations will act in socially responsible way that involves the 
ecosystem. It is, therefore, necessary to take into account the concept of sustainably based organizations founded on ethics, respect for the environment, and knowledge of legal norms.

\subsection{Ethics}

We can consider ethics as the philosophical domain that explores one's critical values, relationships, and behavior toward other people, as well as one's own character and attitude regarding oneself. Ethics may be considered a view of life that contains two elements: the awareness of what is good for humans and an awareness of the responsibilities that a human must meet. Frederick, Davis, and Post (1988) define ethics as a set of rules that tell us when behavior is appropriate and when it is unacceptable and wrong. In their interpretation, ethics primary deals with human relationships and represents a general human trait.

Business ethics is a subdomain of general ethics that appeared only in the twentieth century, although its trunk, general ethics, has been evolving for 2,500 years in the bosom of European philosophy. Interest in business ethics has increased in recent years, partly because of public pressure due to various corruption scandals, disregard for environmental standards, and so on (such as the cases of Enron, Union Carbide in Bhopal, or Exxon Valdez), but also due to organization strategy in response to these pressures (Boatright, 2007; Usrey, 2007; Zelizer, 2007).

Postmodern times represent a challenge to the concept of ethics (Keyes, 2004). It is from this period that the so-called myth of amoral business (De George, 1990) comes; in the West, and especially in the United States, it involves and advocates a widespread belief in the incompatibility of the transaction and fairness. To the present time, prejudices about the separation between economics and ethics are still pulled in different directions by competing interpretations and are much more sensitive to the moral dimension of successful economic performance and life in general. Business ethics is not only a set of rules, but also represents the application of the universal rules of ethics in business activities (Frederick et al., 1988). Ethical problems in the business world often come out of the conflicts of interest between primary and secondary stakeholders, as well as from conflicts within individual stakeholder groups.

In 2010, the ISO 26000 standard aimed to provide guidance on how companies can operate in a socially responsible way, while at the same time increasing their overall performance. This implies an ethical and transparent business that contributes to the health and well-being of its ecosystem and society. The development of this standard has involved representatives of governments, NGOs, industry, consumer groups, and labor organizations from around the world, and an international consensus was reached (ORG ISO, 2013).

It is important to point out how the globalization of markets is challenging the worldwide implementation of sustainable business practices, since there are no laws 
on a global scale which govern the actions of organizations (Chan, Pollard, \& Chuo, 2007; Stiglitz, 2006), which causes the impact of national regulations on organizations to be lost; in their daily work, however, managers must rule according to the norms and values that work (Aßländer \& Brink, 2008).

\subsection{Law}

The law imposes itself on relations between humans and regulates them. Each entity in the business context is expected to comply with laws and rules. Social responsibility requires organizations to adhere to these laws and rules. Ethics and morals, in contrast, govern the relationship between humans and the environment in which they live and regulate the relationship with oneself (Luhmann, 1989).

\subsection{Knowledge}

The development of information technologies in the 1970s led to the opening up of new channels of communication between the various systems that aimed to steer each other. The modern cybernetic science approach bridged the micro-macro gap and has led to higher integration of the individual with society (Bailey, 2006). Cybernetic theory is introduced into science on the epistemological assumption that the only relevant knowledge is obtained from the observation of external reality (Easterby-Smith, Thorp, \& Lowe, 2002). Knowledge has become the force that provides the organization with a competitive advantage. In gaining this, the organization must put in place all the levels (including, e.g., the establishment of corporate culture) necessary to enable it to exploit and use its internal organizational knowledge in everyday activities (Argyris, 1998; Carrion-Cepeda, 2006; Devinney, Midgley, \& Cristine, 2005). Knowledge has very different levels and types (Fig. 1). A fundamental characteristic of knowledge is the possibility of upgrading it, thus increasing the scalability of the system. The higher we climb the pyramid of knowledge (Fig. 1), the more cooperation and global knowledge is needed.

The integration of key strategic instruments allowing the augmentation of knowledge can benefit of the implementation of ad hoc network management policies. Network management is a management style that aims to take advantage of the appropriate synergies between information management, knowledge, and human resources integrated in a global vision, which includes an awareness of the international environment, global markets, and global cultures. Therefore, the creation of "intellectual capital" becomes pivotal for assessing an organization's operations in the present and the future. Intellectual capital can be defined as a combination of knowledge, experience, and equifinality for the organizational goals. Management theory also needs to consider the relevance of hidden resources 

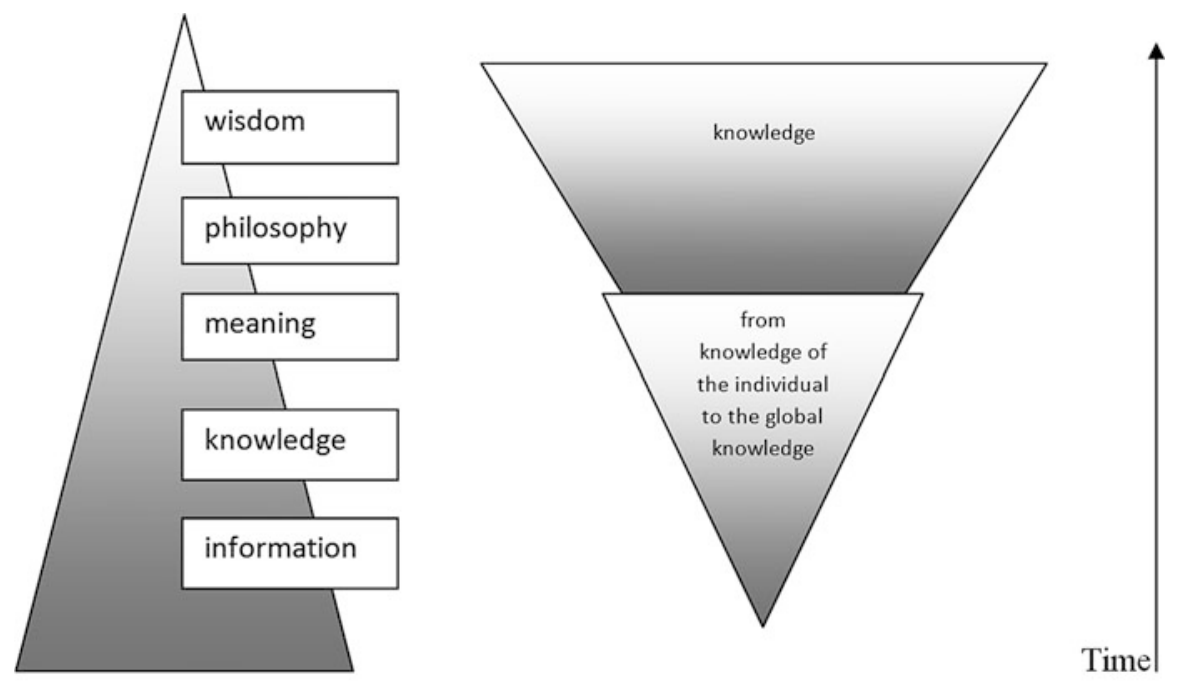

Fig. 1 The pyramid of knowledge. Source: Roblek (2011)

that play a key role in organizations for the development of strategies able to provide a competitive advantage, survive, and be viable in the market (Ross \& Ross, 1997). In order to achieve its aims by establishing fruitful relations with customers and stakeholders, the organization must take into account a system of dynamic hidden relations that are not recorded in its balance sheet-such as the knowledge and skills of its employees and their relationships with the external context (Villalba, 2006).

\subsection{Philanthropy}

Philanthropy is the voluntary decision of an individual or company to help society, in spite of (and disregarding) its economic cost. Philanthropic responsibility can be considered the highest standard of social responsibility, which goes beyond social expectations and thus significantly contributes to the social well-being (Porter \& Kramer, 2002). 


\section{Postmodern Organizational Challenges and Opportunities for Sustainable Management}

Perhaps the core defining divergence between modernism and postmodernism can be traced in postmodernism's denial of the modernist thought that human social knowledge has essential "real" bases. Postmodernism conceives of social actions and knowledge as the mere interplay of myths that produce regimes of truth (Firat, Dholakia, \& Venkatesh, 1995). The new core of analysis becomes the subject over the object. In a postmodern business context, the future is unpredictable and leaders do not have enough knowledge of creative vision, which causes trends such as technology, globalization, competition, change, speed, complexity, and paradox to have a powerful influence on using complexity theory as a management tool (Tetenbaum, 1998).

Sustainable development is one of the critical success factors of postmodern organizations, because customers are becoming increasingly willing to support organizations and purchase products that built their business model on sustainability (Pirsch, Gupta, \& Grau, 2007), thus embedding the myth of being sustainable. The positive image of organizations provides a greater ability to attract capital, business partners, and customers that find self-realizing and convenient to embody the new sustainable myth. For the same reasons, sustainability is becoming an important factor in obtaining, retaining, and motivating employees and in managing human capital.

The primary advantage of sustainable managed organizations is that they are able to answer the challenges of the business environment with a vision that includes finding answers to global issues and ensuring the competitiveness of all employees' at all organizational levels (Goess1, 2010; Schermerhorn, Hunt, \& Osborn, 2002). Organizations need to reconsider their environmental responsibility and to check whether it fits with their basic concept of development; in this way, they affect their organizational culture. At the same time, it must not be forgotten that each group consists of members who come from different social environments. All this affects the culture of the organization. The culture forms the mentality and the frames of references, which are only one of a number of such significant covert processes (Schein, 2010).

The personal values of entrepreneurs and managers have a significant impact on the design of the culture and on organizational vision. It is therefore critical to find ways to address how personal values affect the manager on each business decision about how to achieve better results and avoid the negative impact of technologies on the environment (Grant et al., 2007; Ramus, 2002). The key factors for the achievement of sustainable management goals for an organization can be summarized as follows (Armstrong, 2009; Goessl, 2010; Schermerhorn et al., 2002):

- People are assets: The organization should be able to promote diversity and recognize it as an intangible asset that fosters creativity and innovation, thereby contributing to the creation of added value. 
- Organizing group work: Integration and collaboration are an essential quality of the organization. The organization must promote the creation of an internal environment, which is characterized by the participation and engagement of all employees.

- Integration of new technologies: New technologies make work tasks easier and enable higher productivity. This is because technology makes routine work easier and faster, thus saving employees' time and energies and making it possible for them to engage in more complex tasks.

- Focus on growth and development: Focusing on education and facilitating the personal growth of employees in their field of expertise lead to satisfaction and greater efficiency.

- Communicating objectives: The organizational objectives can be better achieved by implementing visions and taking into account the shared values of all stakeholders.

Managing this issue calls for deep organizational changes, which will lead to new organization structures. Traditional hierarchical systems show several inadequacies when it comes to working in the new business environment. Heterarchical systems can overcome the limits of hierarchical systems, as they are able to achieve flexibility and adaptability to external stimuli, while at the same time increasing the complexity of management within the organization, since their inability to operate following predefined plans means that their behavior is hardly predictable, this increasing the variability and variety in their systemic dynamics. If we consider the organization as an open system embedded in a global and ever-changing external environment, this implies that in a complex environment, the development process cannot be planned in advance, but instead needs to proceed by trial and error, adapting to the new challenges of the environment while, at the same time, considering sustainability issues for the long term.

\section{Conclusions}

In this chapter, we have outlined a research framework for a new management paradigm, attempting to link the main concepts of complexity theory, change management, knowledge management, sustainable development, and cybernetics.

We discussed the transition from the industrial era to the postindustrial age. In the development process, nothing is fixed in advance; we can say that it is opportunistic and adapts to the challenges of the environment, as well as to their effects for and within organizations and society. We saw how the processes of organizational change have occurred as a result of the move to adapt to the changes in the various global and international business environments and how this transformation has led to the shift toward the present innovation economy.

We also pointed out some of the ways in which organizational change needs to deal with sustainability, so that the exploitation of resources, the direction of 
investment, the orientation of technological development, and the institutional change may be consistent with present needs, without compromising the future.

\section{References}

Alexander, C. P. (1983, May 30). The new economy. Time, 62-70. Retrieved April 2014, from: http://content.time.com/time/magazine/article/0,9171,926013,00.html.

Antonelli, C. (2003). The economics of innovation, new technologies and structural change. London: Routledge.

Argyris, C. (1998). Teaching smart people how to learn. In P. F. Drucker (Ed.), Harvard business review on knowledge management (pp. 81-108). Boston: Harvard Business School Press.

Armstrong, M. (2009). Armstrong's handbook of management and leadership: A guide to managing the results. London: Kogan Page.

Aßländer, M. S., \& Brink, A. (2008). Begründung korporativer Verantwortung: Normenkonkretion als Prozess. In G. A. Scherer \& M. Patzer (Eds.), Betriebswirtschaftslehre und Unternehmensethik. Wiesbaden: Gabler.

Autry, W. C., Goldsby, J. T., \& Bell, E. J. (2013). Global macro trends and their impact on supply chain management. Upper Saddle River, NJ: Pearson Education.

Auyang, S. Y. (2003). Foundations of complex-system theories: In economics, evolutionary biology, and statistical physics. New York: Cambridge University Press.

Avery, G. C., \& Bergsteiner, H. (2011a). Sustainable leadership: Honeybee \& Locust approaches. New York: Routledge.

Avery, G. C., \& Bergsteiner, H. (2011b). How BMW successfully practices sustainable leadership principles. Strategy \& Leadership, 39(6), 11-18.

Bailey, K. D. (2006). Sociocybernetics and social entropy theory. Kybernetes, 35(3/4), 375-384.

Barbier, E. B. (1987). The concept of sustainable economic development. Environmental Conservation, 14(02), 101-110.

Bauman, Z. (2000). Liquid modernity. Cambridge: Polity.

Beer, S. (1972). Brain of the firm. London: The Penguin Press.

Bertoncelj, A., Kovac, D., \& Bertoncel, R. (2009). Success factors and competencies in organisational evolution. Kybernetes, 38(9), 1508-1517.

Bertot, C. J., Jaeger, T. P., \& Hansen, D. (2012). The impact of policies on government social media usage: Issues, challenges, and recommendations. Government Information Quarterly, 29(1), 30-40.

Bisson, P., Stephenson, E., \& Vigurie, S. P. (2010). The global grid. http://www.mckinsey.com/ insights/innovation/the_global_grid

Boatright, J. R. (2007). Ethics and the conduct of business. New York: Prentice Hall.

Bonini, S. (2012). The business of sustainability. McKinsey on Sustainability \& Resource Productivity, 96-105. Retrieved March 2014, from: https://www.mckinsey.com/ /media/McKinsey/ dotcom/client_service/Sustainability/PDFs/McK\%20on\%20SRP/SRP_11_Biz\%20sustainability. ashx

Boons, F., Montalvo, C., Quist, J., \& Wagner, M. (2013). Sustainable innovation business models and economic performance: An overview. Journal of Cleaner Production, 45, 1-8.

Boulding, K. E. (1956). General systems theory - the skeleton of science. Management Science, 2 (3), 197-208.

Brinkley, I. (2006). Defining the knowledge economy: Knowledge economy programme report. London: The Work Foundation.

Burke, P. (2012). A social history of knowledge, II. From the Encyclopédie to Wikipedia. Cambridge: Polity. 
Carrion-Cepeda, G. (2006). Competitive advantage of knowledge management. In D. G. Schwartz (Ed.), Encyclopedia of knowledge management (pp. 34-43). London: Idea Group.

Carroll, A., \& Buchholtz, A. (2014). Business and society: Ethics, sustainability, and stakeholder management. Stamford: Cengage Learning.

Certo, S. C. (2000). Modern management: Quality, ethics, and the global environment. New York: Prentice Hall.

Chan, P. S., Pollard, D., \& Chuo, S. (2007). Corporate ethics: China vs. USA. International Business \& Economics Research Journal, 6, 1-8.

Christopher Houghton, B. (2011). Finance at the threshold: Rethinking the real and financial economies. Farnham: Gower Publishing.

Cohen, M. (1999). Commentary on the organization science special issue on complexity. Organization Science, 10(3), 373-376.

Csikszentmihalyi, M. (2004). Good business: Leadership, flow, and the making of meaning. New York: Penguin Books.

De George, R. (1990). Business ethics. New York: McGraw-Hill.

Deresky, H. (2003). International management: Managing across borders and cultures. New York: Prentice Hall.

Devinney, T. M., Midgley, F. D., \& Cristine, W. S. (2005). Knowledge creation in organisations: A multiple study overview. In J. Davis, E. Subrahmanian, \& A. Westerberg (Eds.), Knowledge management: Organizational and technological dimensions (pp. 77-125). Heidelberg: Physica.

Dominici, G. (2008). Holonic production system to obtain flexibility for customer satisfaction. Journal of Service Science and Management, 1(3), 251-254.

Dominici, G. (2012). Consulting of the XXI century. Coping with complex business systems. Nuova Atlantide, 3, 69-77.

Dominici, G., \& Palumbo, F. (2013). Decoding the Japanese lean production system according to a viable systems perspective. Systemic Practice and Action Research, 26(2), 153-171.

Easterby-Smith, M., Thorp, R., \& Lowe, A. (2002). Management research. London: Sage.

Elkington, J. (1999). Triple bottom-line reporting: Looking for balance. Australian CPA, 69(2), 18.

Elliott Dupuy, P. J. (1986). The autonomy of social reality: On the contribution of systems theory to the theory of society. In E. L. Khalil \& K. E. Boulding (Eds.), Evolution, order and complexity. An introduction to sustainable development. London: Routledge.

Emerson, T. (2001). Mystery sold. Newsweek Magazine. Accessed 15 February, 2007, from http:// www.thedailybeast.com/newsweek/2001/01/28/mystery-solved.html

Espejo, R., \& Reyes, A. (2011). Organizational systems: Managing complexity with the viable system model. Berlin: Springer.

European Commission. (2011). Communication from the commission to the European parliament, the council, the European economic and social committee and the committee of the regions. A renewed EU strategy 2011-14 for Corporate Social Responsibility. Accessed August 18, 2014, from http://eur-lex.europa.eu/LexUriServ/LexUriServ.do?uri=COM:2011:0681:FIN:EN:PDF

Firat, F., Dholakia, N., \& Venkatesh, A. (1995). Marketing in a postmodern world. European Journal of Marketing, 29(1), 40-56.

Frederick, C. W., Davis, K., \& Post, E. J. (1988). Business and society: Corporate strategy, public policy, and ethic. New York: McGraw-Hill.

Goessl, L. (2010). What is a high-performance organization (HPO)? Accessed August 16, 2014, from http://www.helium.com/items/802036-what-is-a-high-performance-organization-hpo

Golinelli, G. M. (2010). Viable systems approach (VSA). Padua: Cedam.

Grant, A. M., Campbell, E. M., Chen, G., Cottone, K., Lapedis, D., \& Lee, K. (2007). Impact and the art of motivation maintenance: The effects of contact with beneficiaries on persistence behavior. Organizational Behavior and Human Decision Processes, 103(1), 53-67.

Gresov, C., \& Drazin, R. (1997). Equifinality: Functional equivalence in organization design. Academy of Management Review, 22(2), 403-428. 
Hatch, M. J. (2012). Organization theory: Modern, symbolic and postmodern perspectives. New York: Oxford University Press.

Jackson, K. T. (2010). Scandal beneath the financial crisis: Getting a view from a moral-cultural mental model. Harvard Journal of Law \& Public Policy, 33, 735.

Kaplan, A. M., \& Haenlein, M. (2010). Users of the world, unite! The challenges and opportunities of social media. Business Horizons, 53(1), 59-68.

Kaplan, S. R., \& Mikes, A. (2012). Managing risks: A new framework. Harvard Business Review, 90(6), 49-60.

Keyes, R. (2004). The post-truth era: Dishonesty and deception in contemporary life. New York: St. Martin's Press.

Kieser, A., \& Kubicek, H. (1992). Organisation. Berlin: De Gruyter.

Kuula, M., Putkiranta, A., \& Toivanen, J. (2012). Coping with the change: A longitudinal study into the changing manufacturing practices. International Journal of Operations and Production Management, 32(2), 106-120.

Laszlo, E. (1972). Introduction to systems philosophy: Toward a new paradigm of contemporary thought. New York: Gordon and Breach Science.

Luhmann, N. (1986). The autopoiesis of social systems. In F. Geyer \& J. van der Zouwen (Eds.), Sociocybernetic paradoxes (pp. 172-192). London: Sage.

Luhmann, N. (1989). Ecological communication. Chicago: University of Chicago Press.

Luhmann, N. (1995). Social systems. Stanford: Stanford University Press.

Lynch, D., \& Kordis, P. (1988). Strategy of the dolphin: Scoring a win in a chaotic world. New York: William Morrow.

Merry, U. (1995). Coping with uncertainty: Insights from the new sciences of chaos, self organization and complexity. Westport: Praeger.

Meyer, J. W., \& Rowan, B. (1977). Institutionalized organizations: Formal structure as myth and ceremony. American Journal of Sociology, 83(2), 340-363.

Mikulecky, D. C. (2010). A new approach to the theory of management: Manage the real complex system, not its model. Cybernetics and systems theory in management: Tools, views, and advancements. Hershey, PA: Information Science Reference.

Montalto, F., Behr, C., Alfredo, K., Wolf, M., Arye, M., \& Walsh, M. (2012). Rapid assessment of the cost-effectiveness of low impact development for CSO control. Landscape and Urban Planning, 82(3), 117-131.

Mulej, M., \& Potocan, V. (2007). Requisite holism - precondition of reliable business information. Kybernetes, 36(3/4), 319-332.

Ny, H., Hallstedt, S., \& Ericson, A. (2013). A strategic approach for sustainable product service system development. In A. Chakrabarti (Ed.), CIRP design 2012 (pp. 427-436). London: Springer.

O'Dell, C., \& Hubert, C. (2011). The new edge in knowledge: How knowledge management is changing the way we do business. New York: Wiley.

ORG ISO. (2013). ISO in 2013. Accessed August 20, 2014, from Http://www.iso.org/iso/home/ about/annual_report-2013.html

Pagano, U., \& Rossi, A. M. (2009). The crash of the knowledge economy. Cambridge Journal of Economics, 33(4), 665-683.

Panayotou, T. (2013). Instruments of change: Motivating and financing sustainable development. Oxon: Routledge.

Pearce, D., Barbier, E., \& Markandya, A. (2013). Sustainable development: Economics and environment in the Third World. Stamford, CT: Routledge.

Perry, G., Goodwin, N., Peck, E., \& Freeman, T. (2006). Managing networks of twenty-first century organisations. New York: Palgrave Macmillan.

Pirsch, J., Gupta, S., \& Grau, S. L. (2007). A framework for understanding corporate social responsibility programs as a continuum: An exploratory study. Journal of Business Ethics, 70(2), 125-140. 
Porter, M. E., \& Kramer, M. R. (2002). The competitive advantage of corporate philanthropy. Harvard Business Review, 80(12), 56-68.

Potocan, V., \& Mulej, M. (2003). On requisitely holistic understanding of sustainable development from business viewpoints. Systemic Practice and Action Research, 16(6), 421-436.

Prigogine, I., \& Stengers, I. (1984). Order out of chaos: Man's new dialogue with nature. London: Flamingo.

Ramus, C. A. (2002). Encouraging innovative environmental actions: What companies and managers must do? Journal of World Business, 37(2), 151-164.

Rice, A. L. (2013). The enterprise and its environment: A system theory of management organization. Oxon: Routledge.

Roblek, V. (2011). Knowledge management and fluctuation in technology parks. Master Thesis, University of Primorska, Koper.

Roblek, V., Pejić Bach, M., Meško, M., \& Bertoncelj, A. (2013). The impact of social media to value added in knowledge-based industries. Kybernetes, 42(4), 554-568.

Ross, G., \& Ross, J. (1997). Measuring your company's intellectual performance. Long Range Planning, 30(3), 413-426.

Schein, E. H. (2010). Organizational culture and leadership. San Francisco: Jossey-Bass.

Schermerhorn, J. R., Hunt, G. J., \& Osborn, N. R. (2002). Organizational behavior. New York: Wiley.

Schwartz, M. S., \& Carroll, A. B. (2003). Corporate social responsibility: A three-domain approach. Business Ethics Quarterly, 13, 503-530.

Sekerka, L. E., \& Stimel, D. (2011). How durable is sustainable enterprise? Ecological sustainability meets the reality of tough economic times. Business Horizons, 54(2), 115-124.

Stacey, R. D., Griffin, D., \& Shaw, P. (2000). Complexity and management: Fad or radical challenge to systems thinking? London: Psychology Press.

Staehle, W. H. (1991). Management. Munchen: Verlag F. Vahler.

Stiglitz, J. (2006). Chancen der Globalisierung. München: Siedler.

Stoner, J. A. F., \& Freeman, E. (1992). Management. Englewood Cliffs, NJ: Prentice-Hall.

Teisman, G. R. (2005). Public management on the edge of chaos and order; about leadership and organizing in complexity. The Hague: Academic Service.

Tetenbaum, T. J. (1998). Shifting paradigms: From Newton to chaos. Organizational Dynamics, 26(4), 21-32.

Uhl-Bien, M., Marion, R., \& McKelvey, B. (2007). Complexity leadership theory: Shifting leadership from the industrial age to the knowledge era. The Leadership Quarterly, 18(4), 298-318.

Usrey, K. B. (2007). Ethics in a globalized world - What have we wrought?! International Business \& Economics Research Journal, 6, 41-48.

Valacich, J., \& Schneider, C. (2012). Information systems today: Managing in the digital world. New York: Pearson.

Valentinov, V. (2014). The complexity-sustainability trade - Off in Niklas Luhmann's social systems theory. Systems Research and Behavioral Science, 31(1), 14-22.

van Kleef, J. A. G., \& Roome, N. J. (2007). Developing capabilities and competence for sustainable business management as innovation: A research agenda. Journal of Cleaner Production, 15(1), 38-51.

van Tulder, R., Kolk, A., \& Van Wijk, J. (2009). From chain liability to chain responsibility: MNE approaches to implement safety and health codes in international supply chains. Journal of Business Ethics, 85(2), 399-412.

van Tulder, R., \& Van der Zwart, A. (2006). International business-society management: Linking corporate responsibility and globalization. London: Routledge.

Villalba, E. (2006). The uniqueness of knowledge management in small companies: Managing knowledge as an employer strategy for lifelong learning. Stockholm: US-AB.

von Bertalanffy, L. (1951). General system theory; a new approach to unity of science. Problems of general system theory. Human Biology, 23(4), 302-312. 
von Bertalanffy, L. (1973). General system theory: Foundations, development, applications. New York: George Braziller (Rev. Ed.).

Walters, D. (2004). New economy-new business models-new approaches. International Journal of Physical Distribution \& Logistics Management, 34(3-4), 219-229.

Wiener, N. (1948). Cybernetics. Paris: Hermann.

Wiener, N. (1965). Cybernetics or control and communication in the animal and the machine. Cambridge, MA: MIT press.

Winn, I. M., Kirchgeorg, M., Griffiths, A., Linnenluecke, K. M., \& Günther, E. (2010). Impacts from climate change on organizations: A conceptual foundation. Business Strategy and the Environment, 20, 157-173.

World Business Council for Sustainable Development. (1999). Corporate social responsibility: Meeting changing expectations. Geneva: World Business Council for Sustainable Development.

World Commission on Environment and Development. (1987). Report of the world commission on environment and development: Our common future. Accessed August 19, 2014, from http:// www.un-documents.net/ourcommon-future.pdf

Yang, C.-L., Lin, S.-P., Chan, Y.-H., \& Sheu, C. (2010). Mediated effect of environmental management on manufacturing competitiveness: An empirical study. International Journal of Production Economics, 123(1), 210-220.

Yang, C.-L., \& Sheu, C. (2007). Achieving supply chain environment management: An exploratory study. International Journal of Technology Management, 40(1), 131-156.

Zelizer, V. A. (2007). Ethics in the economy. Zeitschrift für Wirtschafts und Unternehmensethik, 8 (1), 8-23. 